\title{
Pembinaan Kedisiplinan Siswa melalui Penguatan Pendidikan Karakter di Sekolah Dasar
}

\author{
Lenita Puspitasari ${ }^{1}$, Cholis Sa'dijah ${ }^{2}$, Sa'dun Akbar $^{3}$ \\ ${ }^{1}$ Pendidikan Dasar-Universitas Negeri Malang \\ ${ }^{2}$ Pendidikan Matematika-Universitas Negeri Malang \\ ${ }^{3}$ KSDP-Universitas Negeri Malang
}

\section{INFO ARTIKEL}

\section{Riwayat Artikel:}

Diterima: 29-01-2019

Disetujui: 24-05-2019

\section{Kata kunci:}

discipline;

character building;

primary school;

kedisiplinan;

pendidikan karakter;

sekolah dasar

\begin{abstract}
The focus of this study is the implementation of student discipline guidance through class-based PPK, school culture and community participation. This study used a qualitative approach with a case study research design. Sources of data in this study in the form of photographs, field notes, and interviews. This study uses three stages in data analysis, namely data reduction, data presentation, and drawing conclusions. The results of this study indicate that SDN Kauman 1 Malang has implemented disciplinary guidance through PPK in several activities, including (1) class-based KDP starting with planning which includes: making class rules and schedules, class management, and making syllabus and RPP that integrate character values. In the implementation of learning discipline development is carried out through preliminary activities, core, and closing; (2) PPK-based school culture starts from making KTSP, extracurricular activities and habituation; (3) PPK-based community participation starts from making MOu, making a schedule, and PPK activities on the second Saturday of each month. The conclusion of this study is the guidance of student discipline through PPK at Kauman 1 Malang State Elementary School conducted through a class base, school culture, and community participation.
\end{abstract}

ABSTRAK

\begin{abstract}
Abstrak: Fokus penelitian ini yaitu implementasi pembinaan kedisiplinan siswa melalui PPK berbasis kelas, budaya sekolah, dan partisipasi masyarakat. Penelitian ini merupakan pendekatan kualitatif dengan menggunakan rancangan penelitian studi kasus. Sumber data dalam penelitian ini dalam bentuk foto, catatan lapangan, dan hasil wawancara. Penelitian ini menggunakan tiga tahap dalam analisis data, yaitu reduksi data, penyajian data, dan penarikan kesimpulan. Hasil penelitian ini menunjukkan bahwa SDN Kauman 1 Malang telah menerapkan pembinaan kedisiplinan melalui PPK di beberapa kegiatan, di antaranya (1) PPK berbasis kelas dimulai dengan perencanaan yang meliputi pembuatan tata tertib dan jadwal piket kelas, manajemen kelas, serta pembuatan Silabus dan RPP dengan mengintegrasikan nilai karakter. Pada pelaksanaan pembelajaran pembinaan kedisiplinan dilakukan melalui kegiatan pendahuluan, inti, dan penutup; (2) PPK berbasis budaya sekolah dimulai dari membuat KTSP, kegiatan ekstrakurikuler dan pembiasaan; (3) PPK berbasis partisipasi masyarakat dimulai dari pembuatan MoU, pembuatan jadwal, serta kegiatan PPK pada hari Sabtu minggu kedua setiap bulannya. Kesimpulan dari penelitian ini yaitu pembinaan kedisiplinan siswa melalui PPK di SDN Kauman 1 Malang dilakukan melalui basis kelas, budaya sekolah, dan partisipasi masyarakat.
\end{abstract}

\section{Alamat Korespondensi:}

Lenita Puspitasari

Pendidikan Dasar

Universitas Negeri Malang

Jalan Semarang 5 Malang

E-mail: lenita.puspitasari@gmail.com

Pendidikan menjadi hal terpenting dalam hal pembangunan suatu bangsa. Pendidikan karakter merupakan langkah untuk membentuk dan mengembangkan karakter sehingga dapat melahirkan insan yang berkarakter sesuai dengan cita-cita bangsa. Menurut (Jusita, 2016) memaparkan bahwa sebagai sistem penanaman nilai-nilai karakter, implementasi pendidikan karakter haruslah melibatkan seluruh warga sekolah dengan membentuk komponen pengetahuan, kesadaran, kemauan, dan tindakan agar dapat mewujudkan anak bangsa yang berkarakter. Pembinaan nilai karakter ini dilakukan untuk mencetak generasi yang mampu bersaing dan menjawab tantangan dimasa depan. Hal ini sejalan dengan pendapat (Freeks, 2015) menyatakan bahwa pendidikan karakter saat ini bergerak kearah yang benar yang dapat menghasilkan perkembangan keterampilan, pengetahuan, dan moral yang bermanfaat sehingga terbentuklah insan bangsa yang memiliki sikap positif dan mencerminkan nilai dan moral yang baik. 
Penanaman nilai karakter sejak dini dipercaya mampu membentuk karakter pada diri siswa sehingga tidak mudah untuk diubah saat usianya bertambah. (Almerico, 2014) menyatakan bahwa pendidikan karakter di sekolah dasar dilakukan untuk menumbuhkan cara berperilaku yang baik dan berkualitas bagi siswa. Pendidikan karakter sudah digalakkan mulai tahun 2010 dalam Kemendiknas melalui berbagai kegiatan di sekolah. Pelaksanaan pendidikan karakter diwujudkan dengan mengintegrasikan 18 nilai karakter yang termuat dalam Grand Desain 2010 (Kementerian Pendidikan Nasional, 2010). Nilai karakter dikembangkan dalam konteks suatu satuan pendidikan secara komprehensif (the whole school reform), dalam arti dilakukan secara utuh dan menyeluruh baik dalam proses pembelajaran intrakurikuler, kurikuler, serta kegiatan pengembangan bakat minat atau ekstrakurikuler. Pelaksanaan pendidikan karakter haruslah melibatkan peran aktif seluruh warga sekolah, baik dari segi penyusunan program yang mencerminkan nilai karakter, memberikan contoh yang baik bagi peserta, serta melakukan evaluasi kegiatan. Hal ini sejalan dengan pendapat (Anggraini \& Kusniarti, 2016) yang menyatakan bahwa pendidikan karakter akan dapat berjalan dengan baik dan berhasil apabila seluruh stakeholder dapat bekerjasama dengan baik.

Seiring dengan perkembangan zaman, sistem pendidikan nasional di Indonesia semakin berkembang dan mengalami perubahan menuju ke arah sistem pendidikan yang lebih baik. Perubahan kurikulum yang terjadi pada sistem pendidikan merupakan salah satu pengembangan di bidang pendidikan Indonesia yang terus dilakukan untuk perbaikan dan mencapai pendidikan yang berkualitas. Perubahan kurikulum dalam sistem pendidikan di Indonesia diharapkan mampu mempersiapkan generasi emas tahun 2045 dengan dibekali keterampilan abad ke-21. Abad ini membutuhkan transformasi pendidikan secara menyeluruh sehingga untuk menghasilkan kualitas anak bangsa yang mampu membangun rasa ingin tahu, kreatif, inovatif, dan produktif. (Degeng, 1998) menyatakan bahwa lingkungan belajar pada siswa seharusnya memfasilitasi siswa secara bebas untuk berbuat dan menentukan pilihan, hal ini untuk mengembangkan kemampuan mental yang produktif (berpikir kreatif, kritis, dan mandiri).

Salah satu upaya untuk mewujudkan cita-cita penanaman karakter sesuai dengan yang diamanatkan dalam Pancasila dan UUD 1945 telah sepenuhnya didukung oleh Pemerintah. Penetapan (Presiden, 2017) tentang Penguatan Pendidikan Karakter merupakan salah satu bentuk dukungan pemerintah terhadap penanaman karakter anak bangsa di bidang pendidikan. Penguatan pendidikan karakter ini menjadi salah satu program prioritas presiden yang tertuang pada Nawa Cita pembangunan Nasional point ke delapan yang berbunyi "melakukan revolusi karakter bangsa". Hal ini ditindaklanjuti dengan mengutamakan dan membudayakan praktik pendidikan karakter di dunia pendidikan sesuai amanat presiden Republik Indonesia kepada Menteri Pendidikan dan Kebudayaan.

Penguatan pendidikan karakter dilakukan dalam bingkai lima poros nilai utama religius, nasionalisme, gotong royong, integritas, dan mandiri. Implementasi penguatan pendidikan karakter dibangun sebagai fondasi utama pendidikan dan diharapkan dapat mencetak anak bangsa yang dapat menjawab tantangan dimasa depan. Pengintegrasian lima nilai utama penguatan pendidikan karakter dilaksanakan oleh seluruh warga sekolah baik kepala sekolah, guru, staf administrasi, penjaga dan tenaga kebersihan sekolah, siswa, dan masyarakat. Pengintegrasian nilai poros penguatan pendidikan karakter dilakukan secara komprehensif yakni melalui kegiatan di dalam kelas, pengembangan kultur sekolah, dan peran serta masyarakat (Akbar, 2014).

Kedisiplinan sangat dibutuhkan dalam implementasi pendidikan karakter di sekolah. Disiplin merupakan salah satu nilai karakter yang harus dikembangkan dari dalam diri untuk mewujudkan pendidikan karakter di sekolah. (Agboola, Alex \& Tsai, 2012) mengemukakan bahwa pendidikan karakter disiplin merupakan suatu usaha yang dilakukan secara sengaja untuk mengembangkan perilaku etis siswa. Untuk menanamkan nilai kedisiplinan kepada seluruh warga sekolah dibutuhkan konsistensi-dilakukan secara terus-menerus dan konsekuensi-sebagai akibat dari apa yang telah diperbuat. Kedisiplinan sering dikaitkan dengan ketaatan pada segala peraturan. Peraturan yang baik ialah peraturan yang disusun dan dibuat oleh orang yang menjalankan peraturan tersebut. Hal ini disukung oleh pendapat (Rahayuningsih \& Sholikhan, 2016)yang menyatakan bahwa pendidikan karakter terkait dengan kedisiplinan dapat dibangun dengan cara pembuatan jadwal dan aturan yang disepakati bersama. Di sekolah warga sekolah dituntut untuk mampu memfasilitasi siswa dalam mengembangkan perilakunya dan mematuhi aturan sekolah sebagai alat untuk menegakkan kedisiplinan (Lickona, 2013).

SDN Kauman 1 kota Malang merupakan sekolah Adiwiyata mandiri dan sekolah piloting program Penguatan Pendidikan Karakter (PPK) pertama di kota Malang. SDN Kauman 1 Malang juga mendapatkan beberapa penghargaan di bidang pendidikan mutu sekolah, salah satunya pernah meraih juara II tingkat Nasional lomba Penjaminan Mutu tingkat sekolah dasar. SDN Kauman 1 Malang telah melaksanakan pendidikan karakter sejak pemerintah menggalakkan pendidikan karakter pada tahun 2010, mulai dari kegiatan belajar mengajar di kelas, budaya sekolah, dan kegiatan kerjasama dengan masyarakat. Sebagai sekolah piloting PPK, SDN Kauman 1 Malang berkewajiban mensosialisasikan gerakan penguatan pendidikan karakter sekolah melalui pendidikan formal salah satunya adalah jenjang sekolah dasar, serta menumbuhkan motivasi pada satuan pendidikan lainnya untuk mengembangkan nilai karakter dan budaya bangsa pada satuan pendidikan secara kompetitif (keunggulan dalam bersaing). Peneliti ingin menggali lebih dalam serta memberikan gambaran tentang implementasi pembinaan kedisiplinan melalui penguatan pendidikan karakter dengan fokus kelas, budaya sekolah dan partisipasi masyarakat di SDN Kauman 1 Malang. 


\section{METODE}

Penelitian ini merupakan pendekatan kualitatif dengan menggunakan rancangan studi kasus. Metode pengambilan data yang digunakan dalam penelitian ini yaitu (1) wawancara, (2) observasi, dan (3) dokumentasi. Teknik observasi yang digunakan yaitu teknik observasi partisipatif karena peneliti terjun langsung meneliti di SDN Kauman 1 Malang. Selain observasi, pengumpulan data dilakukan dengan wawancara yang dilakukan kepada kepala sekolah, guru, warga sekolah terkait dengan implementasi pembinaan kedisiplinan siswa melalui penguatan pendidikan karakter berbasis kelas, budaya sekolah, dan partisispasi masyarakat. Selanjutnya, studi dokumentasi digunakan dengan tujuan untuk dapat mendukung hasil temuan wawancara dan observasi. Analisis data dilakukan melalui tiga tahap, yaitu mereduksi data, menyajikan data, dan menarik kesimpulan (Miles dan Huberman, 1992).

Temuan hasil penelitian berupa simpulan kemudian dicek keabsahan datanya. Pengecekan keabsahan data dilakukan mulai dari awal penelitian hingga semua data terkumpul. Data yang terkumpul adalah hasil dari observasi, wawancara, dan dokumentasi tentang implementasi pembinaan kedisiplinan siswa melalui penguatan pendidikan karakter berbasis kelas, budaya sekolah, dan partisispasi masyarakat di SDN Kauman 1 Malang. Dalam pengecekan keabsahan data, penelitian kualitatif menggunakan cara ketekunan pengamatan dan triangulasi.

\section{HASIL DAN PEMBAHASAN}

\section{Implementasi Pembinaan Kedisiplinan Siswa melalui Penguatan Pendidikan Karakter}

Hasil yang diperoleh dalam penelitian tentang hasil analisis dengan fokus (1) implementasi pembinaan kedisiplinan siswa melalui penguatan pendidikan karakter berbasis kelas, (2) implementasi pembinaan kedisiplinan siswa melalui penguatan pendidikan karakter berbasis budaya sekolah, dan (3) implementasi pembinaan kedisiplinan siswa melalui penguatan pendidikan karakter berbasis partisipasi masyarakat.

\section{Implementasi Pembinaan Kedisiplinan Siswa melalui PPK Berbasis Kelas}

Berdasarkan data temuan penelitian, perencanaan pembinaan kedisiplinan pada siswa melalui program Penguatan Pendidikan Karakter berbasis kelas di SDN Kauman 1 kota Malang dapat dilakukan melalui tiga kegiatan, yaitu membuat tata tertib dan jadwal piket kelas, manajemen kelas dan membuat pembelajaran yaitu Silabus dan RPP. Tata tertib kelas dan jadwal piket kelas dibuat oleh siswa dan dipatuhi oleh siswa, disamping melatih kedisiplinan pada siswa hal ini dilakukan untuk melatih komitmen dalam membuat kesepakatan. Hal ini sejalan dengan pendapat (Priansa \& Karwati, 2014) yang menyatakan bahwa pembuatan tata tertib kelas dapat dikatan sebagai fungsi perencanaan kelas yang disengaja dibuat untuk mencapai cita-cita bersama dalam kelas. Berikut langkah penting untuk menjalankan fungsi perencanaan kelas, meliputi (a) memberikan pemaparan kepada siswa dan mendata tujuan yang ingin dicapai di dalam kelas; (b) membuat aturan yang harus dipatuhi dan ikuti supaya tujuan kelas tercapai; (c) memberikan kesempatan pada siswa untuk ikut bertanggung jawab atas aturan yang telah mereka buat; dan (d) memperhatikan dan memonitor jalannya tujuan yang telah dibuat bersama. Dengan adanya tata tertib kelas, kedisiplinan pada siswa dapat terbentuk secara terus menerus dan berkelanjutan sehingga mampu menjadi karakter baik dalam diri siswa. Hal ini didukung oleh pendapat (Bayraktar \& Dogan, 2017) yang menyatakan bahwa untuk meningkatkan kedisiplinan siswa, penerapan peraturan dan tata tertib harus dilaksanakan secara konsisten oleh seluruh warga sekolah.

Kegiatan perencanaan tidak terbatas dengan membuat tata tertib dan piket kelas, tetapi dapat dilaksanakan dengan manajemen kelas. Manajemen kelas yang baik membantu anak dalam membentuk nilai kedisiplinan serta membiasakan siswa ikut bertanggung jawab dalam menggunakan, merawat serta menjaga benda-benda yang ada di sekitarnya. Manajemen kelas yang dilakukan guru digunakan sebagai alat penegak kedisiplinan pada siswa. Hal ini sejalan dengan pendapat (Rahim Saidek, Islami, \& Abdoludin, 2016) yang menyatakan bahwa dalam pengelolaan kelas guru perlu membuat catatan pribadi berisi kehadiran, catatan akademis, serta catatan anekdotal tentang siswa sebagai pertimbangan pembuatan aturan kelas. Senada dengan hal tersebut, (Kementerian Pendidikan dan Kebudayaan, 2017) menyatakan bahwa setiap guru mempunyai wewenang untuk membangun kultur kelas serta mengarahkan seluruh komponen kelas agar berkomitmen demi pembelajaran berjalan dengan efektif dan berhasil. Penataan fisik kelas yang dilakukan oleh guru digunakan sebagai alat penegak kedisiplinan pada siswa.

Pembuatan perencanaan pembelajaran berbasis karakter dilakukan dengan cara membuat Silabus dan RPP dengan mengintegrasikan nilai-nilai karakter. Hal ini sejalan dengan pendapat (Wibowo, 2013) yang menyatakan bahwa prosedur pembuatan silabus, RPP, dan bahan ajar yang berwawasan pendidikan karakter dapat dilakukan dengan mengintegrasikan nilai karakter pada silabus, RPP, dan bahan ajar yang telah dirancang sehingga menghasilkan kegiatan pembelajaran yang memfasilitasi pengenalan nilai karakter dan terinternalisasinya nilai karakter dalam kehidupan sehari-hari siswa. Hal ini didukung oleh penelitian (Asriani, 2017)yang memaparkan bahwa pengintegrasian nilai karakter di lingkungan belajar siswa, dapat memberikan siswa pengalaman secara langsung serta sesuai dengan karakteritik siswa.

Dalam melakukan perencanaan pembelajaran, guru SDN Kauman 1 Malang terlebih dahulu menganalisis KI 3 dan KI 4 yang kemudian dilanjutkan merancang strategi serta metode yang akan digunakan saat pembelajaran. Dengan guru memvariasikan model dan metode pembelajaran, siswa dapat memiliki keterampilan abad ke-21 yang sesuai dengan kebutuhannya. Hal ini sejalan dengan (Kementerian Pendidikan dan Kebudayaan, 2016) yang memaparkan bahwa untuk menunjang terbentuknya keterampilan abad-21, guru dapat menggunakan lebih dari satu metode pembelajaran. Metode pembelajaran tersebut, antara lain metode 
pembelajaran saintifik (scientific learning), metode inquiry/discovery learning, metode pembelajaran berbasis proyek (projectbased learning), metode pembelajaran kooperatif (cooperative learning), metode pembelajaran berbasis masalah (problem-based learning), dan metode pembelajaran berbasis teks (text-based instruction/genre based instruction).

Setelah guru merancang model dan metode pembelajaran, selanjutnya ialah mengaitkan nilai-nilai karakter yang sesuai dengan KI 1 dan KI 2. Rangkaian pembuatan perencanaan pembelajaran di atas sejalan dengan pendapat (Akbar, 2016) menyatakan bahwa langkah dalam mengintegrasikan nilai karakter pada pembelajaran dapat dilakukan dengan menganalisis materi pada KI 3 dan dilanjutkan penelaahan pada KI 4 yang akan diajarkan di kelas. Langkah selanjutnya adalah menentukan metode dan strategi pembelajaran yang relevan dengan materi KI 3 dan KI 4 serta dapat memicu nilai-nilai karakter siswa pada proses pembelajaran. Setelah menentukan metode dan strategi pembelajaran, nilai-nilai karakter pada KI 1 dan KI 2 kemudian dikembangkan sesuai dengan materi dan metode pembelajaran yang sudah dirancang. Berdasarkan temuan penelitian di atas, perencanaan pembinaan kedisiplinan pada siswa melalui program Penguatan Pendidikan Karakter berbasis kelas di SDN Kauman 1 Malang, dapat ditarik kesimpulan bahwa perencanaan pembinaan kedisiplinan melalui PPK berbasis kelas di SDN Kauman 1 Malang telah sesuai dengan buku panduan pelaksanaan PPK pada pendidikan dasar. Hal tersebut dapat dilihat dari kegiatan perencanaan pembinaan kedisiplinan siswa SDN Kauman 1 Malang melalui PPK berbasis kelas, mulai dari pembuatan tata tertib dan jadwal piket kelas, manajemen kelas, dan pembuatan perencanaan pembelajaran dengan menginternalisasikan nilai karakter. Hal ini juga ditunjang dengan pendapat (Susanto \& Sa'dijah, 2007) menyatakan bahwa Kurikulum 2013 menginginkan anak bangsa yang bisa menggali pengalaman belajarnya sendiri (konstruktivistik) sehingga pembelajaran yang dilaksanakan sering kali student center. Prinsip utama kontruktivistik adalah pembngunan pengetahuan yang dilakukan oleh siswa secara aktif. Tujuan pembelajaran menggunakan pandangan konstruktivis ialah untuk membangun pemahaman siswa.

Berdasarkan data temuan penelitian, pelaksanaan pembianaan kedisiplinan pada siswa melalui program Penguatan Pendidikan Karakter berbasis kelas dapat dilakukan melalui kegiatan pendahuluan, kegiatan inti, dan kegiatan penutup. Kegiatan pendahuluan yang dilakukan seluruh siswa telah sesuai dengan perencanaan yang dibuat oleh guru yang meliputi: melakukan berdoa bersama, membaca Asmaul Husna, membaca surat-surat pendek Juz Amma, menyanyikan lagu Indonesia Raya/lagu Nasional, menyanyikan lagu Mars PPK, literasi selama 15 menit. Kegiatan selanjutnya yaitu guru mengecek kehadiran siswa, jika ada yang tidak hadir karena sakit guru mengajak siswa untuk mendoakannya. Pada saat guru mekukan apersepsi, siswa terlihat antusias dan melakukan tanya jawab dan diikuti dengan penyampaian tujuan pembeljaran oleh guru. Hal ini merupakan wujud dari nilai-nilai karakter religius, toleransi, Nasionalis, semangat kebangsaan, rasa ingin tahu, dan budaya membaca. Kegiatan pendahuuan ini sesuai dengan (Kementerian Pendidikan dan Kebudayaan, 2016) tentang Standar Proses Pendidikan Dasar dan Menengah. Berikut hal yang harus dilakukan guru dalam kegiatan pendahuluan (1) siswa secara psikologis dan fisik harus dipersiapakan oleh guru supaya dapat mengikuti proses pembelajaran dengan baik; (2) siswa selalu diberikan motivasi belajar dengan cara kontekstual sesuai dengan manfaat dan kegunaan materi ajar di kehidupan sehari-hari. Guru memberikan contoh dan membandingkan dari segi lokal, nasional sampai internasional, serta harus menyesuaikan karakteristik siswa; (3) melakukan apersepsi dengan mengaitkan pengetahuan awal siswa dengan materi yang akan dipelajari; (4) guru menyampaikan tujuan kegiatan pembelajaran yang nantinya harus dicapai oleh siswa; (5) guru memberikan pemapaparan tentang cakupan materi yang akan dipelajari oleh siswa.

Pelaksanaan kegiatan literasi selama 15 menit yang dilakukan SDN Kauman 1 Malang, sesuai dengan buku pedoman pelaksanaan PPK melalui gerakan literasi. (Kementerian Pendidikan dan Kebudayaan, 2017) yang menyatakan bahwa dalam kontes kegiatan PPK berbasis kelas, kegiatan literasi selama 15 menit dapat diintegrasikan pada kegiatan pembelajaran dan mata pelajaran yang ada dalam struktur kurikulum. Pada kegiatan inti yang dilakukan seluruh siswa telah sesuai dengan perencanaan yang dibuat oleh guru yang meliputi kemandirian siswa dalam mengerjakan tugas, siswa dapat menyelesaikan tugas tepat waktu, berani bertanya dan menyampaikan pendapat dengan mengacungkan tangan terlebih dahulu, berkomunikasi dengan menggunakan bahasa Indonesia dengan baik dan santun, menganekaragamkan sumber baca, melakukan kegiatan berkarya secara kelompok, siswa selalu membuang sampah sesuai dengan jenis tempat sampah, serta berani mengkomunikasikan hasil pekerjaannya di depan kelas. Nilai-nilai karakter yang sudah tampak pada siswa, di antaranya mandiri, kerja keras, disiplin, keberanian, komunikatif, gemar membaca, peduli lingkungan, gotong royong, dan percaya diri.

Kegiatan pendahuluan di atas sesuai dengan perencanaan yang dibuat oleh guru. Paparan ini sejalan dengan buku pendoman PPK (Kementerian Pendidikan dan Kebudayaan, 2017) yang menyatakan bahwa salah satu langkah-langkah penerapan PPK melalui pembelajaran adalah melaksanakan pembelajaran sesuai dengan scenario dalam RPP. Dalam temuan penelitian, salah satu pelaksnaan pembelajaran di kelas ialah melakukan kegiatan berkarya secara kelompok. Kegiatan tersebut mencerminkan salah satu cerminan anak berlatih HOPS (High Order Psychomotor Skill) atau disebut dengan kecakapan motorik. Sejalan dengan pendapat (Akbar, Wahyuni, Arafik, Samawi, Marjanto, Relisa, Isbandrianingtyas, 2017) menyatakan bahwa salah satu kecakapan yang harus dimiliki siswa adalah kecakapan psikomotorik tingkat tinggi atau High Order Psychomotor Skill (HOPS). Penekanan pada kecakapan baik afektif, kognitif, dan psikomotor tingkat tinggi membuat posisi pembinaan kedisiplinan melalui penguatan pendidikan karakter sebagai bagian terpenting dalam pembentukan berkarakter baik siswa. Hal ini juga didukung oleh paparan (Sa'dijah, 2013) yang menyatakan bahwa siswa yang dapat berpikir kreatif ditandai dengan memunculkan banyak ide baru untuk memecahkan suatu masalah. Dengan siswa banyak berlatih memecahkan masalah, hal ini akan memicu siswa untuk berpikir kritis. 
Pada kegiatan penutup, siswa menyimpulkan kegiatan belajar mengajar, serta refleksi, kegiatan tindak lanjut, berdoa penutup dan memberikan salam, serta menertipkan bangku masing-masing sebelum meninggalkan kelas. Hal ini merupakan wujud dari nilai-nilai karakter komunikatif, religius, dan tanggungjawab. Kegiatan penutup yang dilakukan siswa dan guru ini sesuai dengan Permen No 22 Tahun 2016 yang menyatakan bahwa kegiatan penutup pembelajaran yang dilakukan dengan membuat kesimpulan atau rangkuman, melakukan penilaian, refleksi kegiatan pembelajaran, melakukan umpan balik yang dapat memotivasi siswa, dan tindak lanjut. Hal ini juga didukung oleh pernyataan (Sa'dijah \& Wahyuningsih, 2004) yang menyatakan bahwa di akhir pembelajaran siswa diberikan kesempatan untuk mengkonfirmasi apa yang sudah mereka kerjakan. Jika terdapat siswa yang belum memahami materi yang diajarkan, guru seharusnya menghargai dengan cara yang positif dan melakukan perbaikan pemahaman siswa dengan mengonfirmasi siswa lain.

Berdasarkan temuan penelitian di atas, pelaksanaan pembinaan kedisiplinan pada siswa melalui program Penguatan Pendidikan Karakter berbasis kelas di SDN Kauman 1 Malang dapat ditarik kesimpulan bahwa pelaksanaan pembinaan kedisiplinan melalui PPK berbasis kelas di SDN Kauman 1 Malang telah sesuai dengan buku panduan pelaksanaan PPK pada pendidikan dasar. Hal tersebut dapat dilihat dari kegiatan perencanaan pembinaan kedisiplinan siswa SDN Kauman 1 Malang melalui PPK berbasis kelas, mulai dari kegiatan pendahuluan, kegiatan inti, dan kegiatan penutup.

\section{Implementasi Pembinaan Kedisiplinan Siswa melalui PPK Berbasis Budaya Sekolah}

Berdasarkan data temuan penelitian pelaksanaan pembinaan kedisiplinan pada siswa melalui program Penguatan Pendidikan Karakter di SDN Kauman 1 Malang berbasis budaya sekolah dapat dilakukan melalui sekolah membuat visi, misi, dan tujuan sekolah dengan melibatkan stakeholder, membuat perencanaan program khusus PPK di sekolah, melakukan penataan fisik, sosial dan psikologis sekolah, serta pembuatan SOP. Dalam membuat perencanaan program PPK sekolah membuat program khusus pelaksanaan PPK dan jadwal kegiatan PPK dalam satu minggu yang meliputi kegiatan pembiasaan, literasi, kegiatan pembelajaran, kegiatan ekstrakurikuler. Pelaksanaan PPK berbasis budaya sekolah di SDN Kauman 1 Malang ini sesuai dengan pendapat (Kurniawan, 2013) yang menyatakan bahwa untuk mengembangkan budaya sekolah dengan mengintegrasikan nilai karate, sekolah perlu memperhatikan beberapa hal, seperti (a) desain gedung sekolah-penataan fisik, sosial, dan psikologis; (b) mekanisme dan tata aturan sekolah, misalnya tata tertib sekolah dan SOP; (c) kegiatan pembiasaan yang diadakan di sekolah; (d) jargon/semboyan sekolah (branding school); (e) filosofi visi, misi sekolah, dan sosialisasinya.

Kegiatan di atas sesuai dengan buku panduan pelaksanaan PPK, bahwa budaya sekolah dapat terlihat dalam sistem pengelolaan sekolah yang mengarah pada praktik pembentukan karakter. Penguatan pendidikan karakter sebagai gerakan Nasional dapat diartikan bahwa setiap satuan pendidikan wajib membuat desain kurikulum dengan mengintegrasikan nilai utama PPK serta menyusun jadwal harian/mingguan (Kementerian Pendidikan dan Kebudayaan, 2017). Hal ini didukung oleh pendapat (Akbar, 2014) yang menyatakan bahwa pembinaan budaya sekolah dapat dilakukan dengan (a) pengintegrasian nilai karakter terhadap pembentukan visi, misi, tujuan, dan moto sekolah; (b) sosialisasi visi, misi, tujuan, dan moto sekolah terhadap stakeholder dalam rangka membentuk komitmen bersama demi ketercapaian cita-cita sekolah; (c) mensosialisasikan peraturan sekolah bagi seluruh stakeholder pendidikan, mulai dari tata tertib bagi siswa, kepala sekolah, guru, staf sekolah, penjual di kantin, hingga bagi orangtua sebagai Standart Operational Prosedure; (d) penyusunan program prioritas sekolah dengan mengintegrasikan nilai karakter melalui kegiatan pembelajaran di kelas, kegiatan pembiasaan, ekstrakurikuler, kegiatan yang melibatkan partisipasi masyarakat, program pengadaan sarana prasarana hingga penyusunan anggaran; (e) mendeskripsikan pelaksanaan program sekolah dengan jelas berserta penanggung jawab program; (f) melakukan penilaian mulai dari telaah, analisis, dan revisi program sekolah sehingga terwujud visi, misi, tujuan, dan moto sekolah yang berorientasi pendidikan karakter. Dengan adanya program khusus PPK pelaksanaan penanaman nilai karakter khusunya kedisiplinan semakin ertanam dengan baik, sebab kegiatan yang dilaksanakan sekolah terbentuk secara sistematis dan dilaksanakan secara terus-menerus serta keberlanjutan.

Pada penataan fisik, sosial, dan psikologis sekolah. SDN Kauman 1 Malang sudah melaksanakan penataan fisik, sosial, dan psikologis dengan baik. Sekolah telah melakukan pengadaan sarana dan prasarana sesuai dengan kebutuhan penanaman nilai karakter. Beberapa sarana dan prasarana yang menunjang penanaman nilai karakter yaitu penataan halaman sekolah, terdapat dua gerbang sekolah sebagai tempat sirkulasi warga sekolah, tempat parkiran guru dan tamu, rak helm, pos satpam, perpustakaan, kantin, air mancur, tempat sampah dan pajangan setiap sudut rangan, sangkar burung, tempat duduk siswa di halaman sekolah, kolam, mushola, tempat pembuatan kompos, green House, almari barang hilang, UKS, laboratorium bahasa dan musik, serta berbagai pohon dan tanaman toga, sayuran, bunga, dan buah-buahan. Penataan sosial dan psikologis terlihat dari beberapa pajangan dan slogan yang bisa ditemui di setiap sudut sekolah dan pajangan tentang tata tertib sekolah, serta ikrar pendidikan karakter, dan budaya malu.

Kegiatan penataan fisik, sosial, dan psikologis sekolah. SDN Kauman 1 Malang ini sesuai dengan pendapat (Akbar, 2011) menyatakan bahwa penataan lingkungan fisik kelas, meliputi (a) pengelolaan ruang kelas yang bersih, rapi, bersinar terang, sejuk-segar, dan kaya sumber belajar; pengadaan aksesori, seperti poster kata-kata bijak, gambar tokoh, serta hasil karya siswa; menciptakan kultur kelas yang mengajarkan siswa untuk membaca, menulis, menyimak, dan mengomunikasikan hal yang sudah mereka baca. Dalam melakukan pengelolaan ruang kelas diperlukan ketersediaan fasilitas dan sumber-sumber informasi di sekolah, seperti buku, surat kabar, dan internet; (b) penataan lingkungan sosial-kultural dan psikologis, lingkungan ini mencakup kegiatan menciptakan interaksi antar komunitas sekolah, misalnya dalam bentuk keyakinan dan harapan, ucapan, sikap, tindakan/perilaku komunitas sekolah yang terwujud dalam pembiasaan yang mencerminkan nilai karakter sehingga membentuk 
kebiasaan hidup. Berdasarkan paparan di atas, penataan fisik, sosial, dan psikomotor dapat menjadi salah satu alat untuk pembentukan karakter baik pada siswa, khususnya kedisiplinan.

SDN Kauman 1 Malang memiliki beberapa SOP dalam melaksanakan setiap kegiatan di sekolah. SOP dibuat sebagai dasar pelaksanaan kegiatan sekolah yang menyangkut beberapa standar berdasarkan badan standar nasional pendidikan (BSNP). Dalam kaitannya dengan program PPK sekolah terdapat beberapa SOP yang berkaitan dengan PPK berbasis kelas, budaya sekolah, dan partisipasi masyarakat. Dengan adanya SOP pelaksanaan seluruh kegiatan sekolah dapat berjalan dengan mudah, rapi dan tertib sesuai dengan perencanaan. Hal ini sesuai dengan pendapat (Suryanto, 2016) yang menyatakan bahwa SOP berisi petunjuk dan cara yang diperlukan oleh guru/pegawai untuk melaksanakan pekerjaan mereka. SOP bermanfaat sebagai standarisasi dalam menyelesaikan kegiatan dan mengurangi tingkat kesalahan dalam menyelesaikan kegiatan.

Berdasarkan temuan penelitian di atas, pelaksanaan pembinaan kedisiplinan pada siswa melalui program Penguatan Pendidikan Karakter berbasis budaya sekolah di SDN Kauman 1 Malang dapat ditarik kesimpulan bahwa desain kurikulum dalam hal ini menginternalisasikan nilai karakter ke dalam visi, misi, dan tujuan sekolah, penataan fisik, sosial, dan psikomotor, serta adanya SOP yang dilaksanakan di SDN Kauman 1 Malang kurang sesuai dengan buku panduan pelaksanaan PPK pada pendidikan dasar. Hal tersebut dapat dilihat dari kegiatan perencanaan pembinaan kedisiplinan siswa SDN Kauman 1 Malang melalui PPK berbasis budaya sekolah, mulai dari menginternalisasikan nilai karakter ke dalam visi, misi, dan tujuan sekolah, membuat program khusus PPK, dan jadwal mingguan kegiatan PPK, penataan fisik, sosial dan psikomotor, serta adanya SOP. SDN Kauman 1 Malang belum memiliki branding school yang memayungi kegiatan PPK di sekolah.

Berdasarkan data temuan penelitian, kegiatan ekstrakurikuler di SDN Kauman 1 Kota Malang terbagi menjadi dua, yaitu ekstrakurikuler wajib dan pilihan. Hal ini sesuai dengan (Kementerian Pendidikan dan Kebudayaan, 2017) yang menyatakan bahwa ekstrakurikuler wajib tingkat satuan pendidikan dasar pada umumnya adalah pendidikan kepramukaan, sedangkan ekstrakurikuler pilihan disesuaikan dengan bakat, minat siswa dan kegiatan yang dikembangkan sesuai dengan visi, misi masingmasing satuan pendidikan. Ekstrakurikuler pramuka merupakan ekstrakurikuler wajib dan dalam pelaksanaannya telah menanamkan kedisiplinan dalam berbagai kegiatan, di antaranya siswa berkumpul tepat pukul 12.30 WIB, siswa memakai pakaian pramuka lengkap dan rapi, kegiatan dimulai dengan berbaris dengan tertib diikuti dengan berdoa bersama, dan terdapat beberapa kegiatan pembiasaan, sebagai contoh membuang sampah pada tempatnya, kompak dalam bekerjasama, kerja keras, dan bertanggung jawab dalam menyelesaikan tugasnya. Kegiatan di atas dapat menumbuhkan nilai karakter pada siswa, seperti disiplin, religius, peduli lingkungan, kreatif, gotong royong, dan nasionalis.

Ekstrakurikuler pilihan SDN Kauman 1 Malang, meliputi karate, mewarna, club sains, Shinkenjuku, seni tari, band, menganyam/membatik, paduan suara, robot kids, basket, futsal, renang, dan seni lukis. Pelaksanaan ekstrakurikuler pilihan telah mencerminkan kedisiplinan dalam berbagai kegiatan, di antaranya siswa berkumpul tepat pukul 12.30 WIB, siswa memakai pakaian sesuai dengan jenis ektrakurikuler yang diikuti (rapi dan sopan), kegiatan dimulai dengan berdoa bersama, dan terdapat beberapa kegiatan pembiasaan, sebagai contoh membuang sampah pada tempatnya, membersihkan tempat ekstrakurikuler setelah digunakan, dapat bersungguh-sungguh dalam bekerjasama dan kerja keras serta bertanggung jawab untuk menyelesaikan tugasnya. Nilai komunikatif terlihat saat siswa berkomunikasi dengan pelatih menggunakan bahasa Indonesia dengan baik dan sopan kepada guru pembina ekstrakurikuler maupun dengan teman sebaya. Kegiatan ekstrakurikuler pilihan di SDN Kauman 1 Malang sejalan dengan Direktorat Pembinaan Sekolah Dasar (2012) yang menyatakan bahwa kegiatan ektrakurikuler disediakan oleh sekolah sesuai dengan minat siswa dalam rangka mengembangkan, mengakomodasi, memfasilitasi minat, bakat, aspirasi, dan harapan siswa.

Berdasarkan temuan penelitian di atas, pelaksanaan pembinaan kedisiplinan pada siswa melalui program Penguatan Pendidikan Karakter berbasis budaya sekolah di SDN Kauman 1 Malang dapat ditarik kesimpulan bahwa kegiatan ekstrakurikuler yang dilaksanakan di SDN Kauman 1 Malang telah sesuai dengan buku panduan pelaksanaan PPK pada pendidikan dasar. Hal tersebut dapat dilihat dari kegiatan pelaksanaan pembinaan kedisiplinan siswa SDN Kauman 1 Malang melalui PPK berbasis budaya sekolah pada kegiatan ekstrakurikuler sekolah, mulai dari ekstrakurikuler pramuka dan ekstrakurikuler pilihan. Dengan adanya kegiatan ekstrakurikuler di sekolah, siswa dapat menumbuhkan nilai kedisiplinan dan tanggung jawab.

Pelaksanaan pendidikan karakter melalui budaya sekolah terlihat dari kegiatan pembiasaan. Kegiatan pembiasaan yang dilakukan SDN Kauman 1 Malang, meliputi kegiatan rutin, spontan, dan keteladanan. Hal ini sejalan dengan (Kementerian Pendidikan Nasional, 2010) tentang penanaman 18 nilai karakter, salah satu basis penanaman nilai karakter adalah melalui pembiasaan yang terdiri dari kegiatan rutin, spontan, dan keteladanan. Kegiatan rutin terlihat pada kegiatan jabat tangan setiap pagi sebelum masuk sekolah, pemakaian seragam sekolah, berbaris sebelum masuk kelas, berdoa sebelum dan sesudah belajar, membaca Asmaul Husna, menyanyikan lagu Indonesia Raya dan lagu Nasional, upacara bendera hari Senin, doa bersama di halaman sekolah, piket kelas, Jumat bersih, senam sehat ceria anak Indonesia, sholat berjamaah, infaq, shalat jumat dan keputrian, serta peringatan hari besar dan agama Nasional. Nilai-nilai karakter yang sudah terintegrasi yaitu disiplin, religius, semangat kebangsaan, cinta tanah air, tanggung jawab, peduli lingkungan, peduli sosial, dan toleransi. Kegiatan rutin di SDN Kauman 1 Malang dilaksanakan secara sistematis dan terus menerus dan berkelanjutan. Hal ini sesuai dengan pendapat (Samani, 2012) yang menyatakan bahwa kegiatan yang dilaksanakan siswa secara terus-menerus di sekolah disebut juga dengan kegiatan rutin.

Pada kegiatan spontan, meliputi mengumpulkan sumbangan, memberi nasehat secara langsung kepada siswa yang berbuat salah, membuang sampah pada tempatnya, meletakkan barang yang hilang ke dalam almari, dan keaktifan siswa dalam belajar. Nilai-nilai karakter yang sudah terintegrasi yaitu peduli sosial, bersahabat, toleransi, peduli lingkungan, kerja keras, 
tanggung jawab, rasa ingin tahu, dan jujur. Kegiatan spontan di SDN Kauman 1 Malang muncul pada saat waktu tertentu tanpa terencana. Hal ini sesuai dengan pendapat (Gunawan, 2012) yang menyatakan bahwa kekuatan spontan adalah kegiatan yang dilakukan spontan atau pada saat itu juga yang dilakukan oleh siswa. Sementara itu, bentuk keteladanan yang dilakukan guru SDN Kauman 1 Malang, meliputi guru datang tepat waktu, menggunakan bahasa baik dan sopan, berpakaian rapi, membiasakan berjabat tangan saat bertemu, serta melaksanakan program Sekolah Ramah Anak. Nilai-nilai yang terintegrasi yaitu disiplin dan komunikatif. Kegiatan keteladanan oleh guru dan warga sekolah yang dilaksanakan secara sengaja di sekolah sehingga dapat menjadi contoh bagi siswa di sekolah. Hal ini sejalan dengan pendapat (Gunawan, 2012) yang menyataan bahwa kegiatan keteladanan adalah perilaku pemberian contoh oleh guru dan tenaga kependidikan baik melalui tindakan dan perkataan yang baik agar menjadi teladan dan panutan bagi siswa.

Berdasarkan temuan penelitian di atas, pelaksanaan pembinaan kedisiplinan pada siswa melalui program Penguatan Pendidikan Karakter berbasis budaya sekolah di SDN Kauman 1 Malang dapat ditarik simpulan bahwa kegiatan pembiasaan yang dilaksanakan di SDN Kauman 1 Malang telah sesuai dengan peraturan Kemendiknas 2010 tentang penanaman 18 nilai karakter, salah satu basis penanaman nilai karakter adalah melalui pembiasaan yang terdiri dari kegiatan rutin, spontan, dan keteladanan. Pembiasaan dapat dilaksanakan untuk menanamakan nilai kedisiplinan pada siswa, hal ini disebabkan oleh kegiatan pembiasaan di sekolah telah terencana secara sistematik dan dilaksanakan secara terus menerus. Melalui pembiasaan, siswa terbiasa berperilaku yang mencerminkan karakter baik.

\section{Implementasi Pembinaan Kedisiplinan Siswa melalui PPK Berbasis Partisipasi Masyarakat}

Berdasarkan temuan penelitian, perencanaan implementasi pembinaan kedisiplinan siswa melalui penguatan pendidikan karakter berbasis partisipasi masyarakat di SDN Kauman 1 Malang dimulai dengan surat pengantar dan MoU dari instansi masyarakat di luar lingkungan sekolah. Hal ini sesuai dengan pendapat (Suryanto, 2016) yang menyatakan bahwa sekolah sebagai instansi yang menjalin kerjasama harus berinisiatif untuk membuat dokumen yang berisi informasi tentang tata cara bekerjasama. Menjalin kerjasama dengan masyarakat (instansi, perusahaan) perlu adanya payung MoU sebagai panduan tentang bekerjasama serta dibuat oleh kedua belah pihak yang bekerjasama. Setelah administrasi partisipasi masyarakat selsesai, SDN Kauman 1 Malang melakukan kegiatan penjadwalan program PPK berbasis partisipasi masyarakat untuk menjaga berjalannya kegiatan PPK berbasis partisipasi masyarakat di SDN Kauman 1 Malang berjalan sesuai dengan kebutuhan. Dalam menyusun jadwal pelaksanaan PPK di sekolah Waka Humas mempertimbangkan situasi, kondisi, waktu, serta bentuk kerjasama yang ingin dilaksanakan. Bentuk kerjasama yang dapat dilaksanakan, meliputi finansial, material, akademik, kultural, dan evaluatif (Sastropoetro, 1998).

Berdasarkan temuan penelitian di atas, pelaksanaan pembinaan kedisiplinan pada siswa melalui program Penguatan Pendidikan Karakter berbasis partisispasi masyarakat di SDN Kauman 1 Malang dapat ditarik kesimpulan bahwa kegiatan perencanaan pelaksanaan PPK berbasis Masyarakat telah sesuai sesuai dengan (Kementerian Pendidikan Nasional, 2011). Hal tersebut dikarenakan SDN Kauman 1 Malang telah melaksanakan kegiatan kerjasama sesuai dengan (Kementerian Pendidikan Nasional, 2011), meliputi (a) menerima semua keputusan secara bijak oleh komite sekolah; (b) memberikan bantuan berupa dana, bahan, dan tenaga; (c) melakukan konsultasi apabila mengalami kesulitan yang berkaitan dengan siswa; (d) ikut aktif dalam kegiatan praktik pendidikan karakter di sekolah; (e) ikut serta sebagai pelaksana kegiatan, misalnya penyuluhan tentang kesehatan, parenting, dan lain sebagainya; (f) ikut serta dalam pengambilan keputusan yang berkaitan dengan pembinaan pendidikan karakter.

Berdasarkan temuan penelitian, pelaksanaan implementasi pembinaan kedisiplinan siswa melalui penguatan pendidikan karakter berlangsung secara rutin. Kegiatan PPK berbasis pasrtisipasi masyarakat dilakukan setiap bulan di minggu kedua pada hari Sabtu. Setiap pekan PPK dilaksanakan, SDN Kauman 1 Malang selalu memberikan kesempatan kepada mitra untuk berkerjasama. Kegiatan kewirausahaan sengaja diplih oleh SDN Kauman 1 Malang untuk menjadi program khusus di pekan PPK. Kegiatan kewirausahaan dilakukan oleh siswa kelas tinggi, sedangkan pada kelas lebih kepada kegiatan kreativitas siswa. Pelaksanaan pembinaan kedisiplinan siswa melalui penguatan pendidikan karakter berbasis partisipasi masyarakat di SDN Kauman 1 Malang, tidak terbatas dengan kegiatan kewirausahaan saja, tetapi beberapa bentuk yang dilaksanakan, meliputi finansial, material, akademik, kultural, dan evaluatif (Sastropoetro, 1998). Beberapa nilai karakter yang muncul saat kegiatan pekan PPK ialah disiplin, kerjasama, percaya diri, tanggung jawab, dan komunikatif.

Berdasarkan temuan penelitian di atas, pelaksanaan pembinaan kedisiplinan pada siswa melalui program Penguatan Pendidikan Karakter berbasis partisispasi masyarakat di SDN Kauman 1 Malang dapat ditarik kesimpulan bahwa kegiatan perencanaan pelaksanaan PPK berbasis Masyarakat telah sesuai sesuai dengan (Kementerian Pendidikan dan Kebudayaan, 2017). Sebab SDN Kauman 1 Malang telah melaksanakan kegiatan kerjasama sesuai dengan (Kementerian Pendidikan dan Kebudayaan, 2017), meliputi pembelajaran di luar kelas (outing class) museum, cagar budaya, dan sanggar, mentoring dengan seniman dan budayawan lokal, kelas inspirasi, program siaran radion on-air, kolaborasi dengan media televisi, koran, dan majalah, gerakan literasi, literasi digital, kolaborasi dengan perguruan tinggi: riset dosen-guru, program magang kerja, kerja sama dengan komunitas keagamaan. PPK Berbasis Partisispasi Masyarakat melalui kegiatan kewirausahaan dapat menanamkan nilai karakter disiplin, jujur, percaya diri, gotong royong, keberanian, dan komunikatif. 


\section{SIMPULAN}

Berdasarkan pembahasan, secara umum dapat disimpulkan bahwa SDN Kauman 1 Malang telah menerapkan pembinaan kedisiplinan siswa melalui Penguatan Pendidikan Karakter berbasis kelas, budaya sekolah, dan partisipasi masyarakat. Penerapan pembinaan kedisiplinan siswa melalui penguatan pendidikan karakter berbasis kelas di SDN Kauman 1 Malang dimulai dengan kegiatan membuat tata tertib dan jadwal piket kelas, manajemen kelas yang dilakukan oleh guru, serta pembuatan perangkat pembelajaran yaitu Silabus dan RPP dengan mengintegrasikan nilai-nilai karakter. Pada pelaksanakan pembelajaran guru telah melakukan upaya penanaman nilai-nilai karakter dimulai dari kegiatan pendahuluan, kegiatan inti, dan kegiatan akhir. Nilai-nilai karakter yang muncul, di antaranya religius, toleransi, nasionalis, semangat kebangsaan, rasa ingin tahu, dan budaya membaca.

Penerapan pembinaan kedisiplinan siswa melalui PPK berbasis budaya sekolah di SDN Kauman 1 Malang dimulai dengan membuat visi, misi, dan tujuan sekolah dengan melibatkan stakeholder, membuat perencanaan program khusus PPK di sekolah serta melakukan penataan fisik, sosial, dan psikologis sekolah untuk memfasilitasi pendidikan karakter. Tidak hanya sarana prasarana yang memadai SDN Kauman 1 Malang juga pembuatan SOP (Standar Operasional Sekolah). Dengan adanya SOP pelaksanaan seluruh kegiatan sekolah akan berjalan dengan baik dan dapat membuat sekolah lebih inovatif untuk melaksanakan ide yang melebihi dari standar yang telah dibuat.

Penerapan pembinaan kedisiplinan siswa melalui PPK berbasis budaya sekolah di SDN Kauman 1 Malang juga dilakukan dalam kegiatan ekstrakurikuler. SDN Kauman 1 Malang terbagi menjadi dua, yaitu ekstrakurikuler wajib dan pilihan. Ekstrakurikuler pramuka merupakan ekstrakurikuler wajib sedangkan ekstrakurikuler pilihan yang ada di SDN Kauman 1 Malang, meliputi karate, mewarna, club sains, Shinkenjuku, seni tari, band, menganyam/membatik, paduan suara, robot kids, basket, futsal, renang dan seni lukis. Pelaksanaan semua kegiatan ekstrakurikuler sudah mencerminkan nilai-nilai karakter, di antaranya (1) peserta datang tepat waktu, (2) peserta memulai kegiatan dengan berdoa bersama, (3) peserta melakukan kegiatan ekstrakurikuler dengan sungguh-sungguh, (4) peserta dalam berkomunikasi antar teman menggunakan bahasa Indonesia dengan baik dan sopan, (5) peserta membersihkan tempat latihan setelah latihan selesai, (6) kompak dalam melaksanakan tugas kelompok, dan (7) siswa memakai pakaian sesuai dengan jenis ektrakurikuler yang diikuti (rapi dan sopan). Berikut nilai-nilai karakter yang terwujud dalam kegiatan ektrakurikuler, meliputi disiplin, religius, peduli lingkungan, kreatif, kerja keras, komunikatif, gotong royong, dan nasionalis. Penerapan pembinaan kedisiplinan siswa melalui PPK berbasis budaya sekolah di SDN Kauman 1 Malang juga dilakukan dalam kegiatan pembiasaan yang meliputi kegiatan rutin, kegiatan spontan, dan keteladanan yang dilakukan oleh guru. Berikut nilai-nilai karakter yang terwujud dalam kegiatan pembiasaan: Nilai-nilai karakter yang sudah terintegrasi yaitu disiplin, religius, semangat kebangsaan, cinta tanah air, tanggung jawab, peduli lingkungan, peduli sosial, dan toleransi.

Penerapan pembinaan kedisiplinan siswa melalui penguatan pendidikan karakter berbasis partisispasi masyarakat di SDN Kauman 1 kota Malang dimulai dengan surat pengantar dan MoU dari instansi masyarakat di luar lingkungan sekolah. Setelah administrasi partisipasi masyarakat selsesai, SDN Kauman 1 Malang melakukan kegiatan penjadwalan program PPK berbasis partisispasi masyarakat untuk menjaga berjalannya kegiatan PPK berbasis partisipasi masyarakat di SDN Kuman 1 Malang berjalan sesuai dengan kebutuhan. Dalam menyusun jadwal pelaksanan PPK di sekolah Waka Humas mempertimbangkan situasi, kondisi, waktu, serta bentuk kerjasama yang ingin dilaksanakan.

Pelaksanaan implementasi pembinaan kedisiplinan siswa melalui penguatan pendidikan karakter berbasis partisipasi masyarakat di SDN Kauman 1 Malang berlangsung secara rutin. Kegiatan PPK berbasis pastisipasi masyarakat dilakukan setiap bulan di minggu ke dua pada hari Sabtu. Setiap pekan PPK dilaksanakan, SDN Kauman 1 Malang selalu memberikan kesempatan kepada mitra untuk berkerjasama. Kegiatan kewirausahaan sengaja diplih oleh SDN Kauman 1 Malang untuk menjadi program khusus di pekan PPK. Tidak terbatas dalam kegiatan kewirausahaan saja, tetapi beberapa bentuk partisipasi masyarakat yang dilaksanakan di SDN Kauman 1 Malang, seperti finansial, material, akademik, kultural, dan evaluatif.

Berdasarkan simpulan penelitian, disarankan agar (1) sekolah dasar kota Malang yang memiliki karakteristik kurang dalam mengintegrasikan nilai kedisiplinan di kelas disarankan untuk melaksanakan pembinaan kedisiplinan siswa melalui Penguatan Pendidikan Karakter berbasis kelas dengan membuat tata tertib kelas, manajemen kelas, dan perencanaan pembelajaran dengan mengintegrasikan nilai karakter; (2) sekolah dasar kota Malang yang memiliki karakteristik kurang dalam mengintegrasikan nilai kedisiplinan pada budaya sekolah disarankan untuk melaksanakan pembinaan kedisiplinan siswa melalui Penguatan Pendidikan Karakter berbasis budaya sekolah dengan membuat desain KTSP berkarakter, kegiatan ekstrakurikuler, dan kegiatan pembiasaan; (3) sekolah dasar kota Malang yang memiliki karakteristik kurang dalam mengintegrasikan nilai kedisiplinan dalam menjalin kerjasama dengan masyarakat disarankan untuk melaksanakan pembinaan kedisiplinan siswa melalui Penguatan Pendidikan Karakter berbasis partisipasi masyarakat dengan membuat MoU kerjasama dengan instansi luar sekolah serta melaksanakan program kewirausahaan sesuai dengan karakteristik sekolah; (4) berdasarkan hasil penelitian, SDN Kauman 1 Malang belum membuat tagline yang akan menjadi branding school yang menunjukkan kekhasan, keunikan, dan keunggulan sekolah. Maka disarankan untuk peneliti selanjutnya dapat meneliti branding school di sekolah. 


\section{DAFTAR RUJUKAN}

Agboola, Alex \& Tsai, K. C. (2012). Bring Character Education into Classroom. European Journal of Educational Research, 1(2), 163-170. https://doi.org/10.1017/CBO9781107415324.004

Akbar, S, Wahyuni, S, Arafik, M, Samawi, A, Marjanto, D. K, Relisa, Isbandrianingtyas, N. (2017). Laporan Penelitian Kebijakan Pendidikan "Penguatan Pendidikan Karakter di Sekolah Dasar." Jakarta.

Akbar, S. (2011). Revitalisasi Pendidikan Karakter di Sekolah Dasar. Malang: Pidato Pengukuhan Guru Besar pada Sidang Terbuka, Universitas Negeri Malang.

Akbar, S. (2014). Revitalisasi Pendidikan Karakter pada Satuan Pendidikan dengan Pendekatan Komprehensif. In Seminar Pendidikan Karakter Bangsa, Fakultas Sastra Universitas Negeri Malang, Malang 1 November.

Almerico, G. M. (2014). Building Character Through Literacy with Children's Literature. Research in Higher Education Journal, 26, 1-13.

Anggraini, P., \& Kusniarti, T. (2016). The Implementation of Character Education Model Based on Empowerment Theatre for Primary School Students. Journal of Education and Practice, 7(1), 26-29. https://files.eric.ed.gov/fulltext/EJ1089767.pdf

Bayraktar, H. V., \& Dogan, M. C. (2017). Investigation of Primary School Teachers' Perception of Discipline Types They Use for Classroom Management. Higher Education Studies, 7(1), 30. https://doi.org/10.5539/hes.v7n1p30

Degeng, I. N. S. (1998). Mencari Paradigma Baru Pemecahan Masalah Belajar dari Keteraturan Menuju Kesemrawutan. Pengukuhan Guru Besar UM. https://doi.org/10.4324/9780203102992

Freeks, F. E. (2015). The Influence of Role-Players on the Character-Development and Character-Building of South African college students. South African Journal of Education, 35(3), 1-13. https://doi.org/10.15700/saje.v35n3a1086

Gunawan, H. (2012). Pendidikan Karakter Konsep dan Implementasi. Bandung: Alfabeta.

Kementerian Pendidikan dan Kebudayaan. (2017). Konsep dan Pedoman Penguatan Pendidikan Karakter. Jakarta: Kementerian Pendidikan dan Kebudayaan.

Kurniawan, S. (2013). Pendidikan Karakter "Konsepsi \& Implementasinya Secara Terpadu di Lingkungan Keluarga, Sekolah, Perguruan Tinggi, dan Masyarakat. Yogyakarta: Ar-Ruzz Media.

Lickona, T. (2013). Character Matters-Persoalan Karakter Bagaimana membantu Anak Mengembangkan Penilaian yang Baik, Integritas, dan Kebajikan Penting Lainnya. Jakarta: Bumi Aksara.

Priansa, J. \& Karwati, E. (2014). Manajemen Kelas-Classroom Management-Guru Profesional yang Inspiratif, Kreatif, Menyenangkan, dan Berprestasi. Bandung: Alfabeta.

Rahayuningsih, S., \& Sholikhan. (2016). Disciplinary Character Education at Early Age. IOSR Journal of Research \& Method in Education, 6(5), 42-49. https://doi.org/10.9790/7388-0605024249

Rahim Saidek, A., Islami, R., \& Abdoludin. (2016). Character Issues: Reality Character Problems and Solutions through Education in Indonesia. Journal of Education and Practice, 7(17), 158-165.

Sa'dijah, C. (2013). Kepekaan Bilangan Siswa SMP melalui Pembelajaran Matematika Kontekstual dan Mengintegrasikan Keterampilan Berpikir Kreatif. Jurnal Pendidikan dan Pembelajaran, 20(2), 222-227.

Sa'dijah, C., \& Wahyuningsih, S. (2004). Pembelajaran Matematika yang Berbasis Pendekatan Problem Open-Ended untuk Meningkatkan Kemampuan Pemecahan Masalah Matematika Siswa SLTP. Jurnal Pendidikan \& Pembelajaran, 11(1), $39-47$.

Samani, M. \& H. (2012). Konsep dan Model Pendidikan Karakter. Bandung: Rosdakarya.

Sastropoetro, S. (1998). Partisipasi, Komunikasi, Persuasi, dan Disiplin dalam Pembangunan Nasional. Bandung: Alumni.

Suryanto. (2016). Administrasi Publik untuk Pelayanan Publik. Bandung: Alfabeta.

Wibowo, A. (2013). Manajemen Pendidikan Karakter di Sekolah: Konsep dan Praktik Implementasi. Yogyakarta: Pustaka Pelajar. 